\title{
Quick Clay Development and Cation Composition of Pore Water in Marine Sediments from the Ariake Bay Area, Japan
}

\author{
Phanny He1, Masami Ohtsubo', Hiroshi Abe', Takahiro Higashi' ${ }^{1}$, Motohei Kanayama² \\ ${ }^{1}$ Department of Bioproduction Environmental Sciences, Kyushu University, Fukuoka, Japan \\ ${ }^{2}$ Department of Environmental Sciences for Sustainability, Iwate University, Morioka, Japan \\ Email: he phanny@yahoo.com
}

Received 17 March 2014; revised 16 April 2014; accepted 2 May 2014

Copyright (C) 2014 by authors and Scientific Research Publishing Inc.

This work is licensed under the Creative Commons Attribution International License (CC BY).

http://creativecommons.org/licenses/by/4.0/

(c) (i) Open Access

\begin{abstract}
By analyzing the cation composition of pore water in the soil samples of Ariake Bay sediments, the present study assesses the development of quick clay by leaching in both the original and seawater-saturated soil samples. Divalent cations were dominant in the pore water of the original soil sample, whereas $\mathrm{Na}^{+}$was the major cation in that of the seawater-saturated soil sample. The cation proportion in the pore water for both soil samples remained the same after leaching. The difference in pore water cation composition between the original and seawater-saturated soil samples affected how their geotechnical properties changed through leaching. The undisturbed shear strength of both soil samples remained almost the same, but a large disparity between the soil samples was observed in the remolded shear strength: it remained almost the same in the original soil sample after leaching. Hence, sensitivity was not increased and quick clay was not formed. However, in the seawater-saturated soil sample, the remolded shear strength decreased to a great extent, and quick clay with a sensitivity exceeding $\mathbf{7 0 0}$ developed. The lack of development of quick clay in the original soil sample is attributed to the dominance of divalent cations in the pore water, and the development of quick clay in the seawater-saturated soil sample is ascribed to the dominance of $\mathrm{Na}^{+}$in the pore water.
\end{abstract}

\section{Keywords}

Ariake Sediment, Salt Leaching, Quick Clay, Divalent Cation, Shear Strength, Sensitivity

\section{Introduction}

Marine soft clay has a flocculated structure and aggregated arrangement that provides a framework with an in-

How to cite this paper: He, P., et al. (2014) Quick Clay Development and Cation Composition of Pore Water in Marine Sediments from the Ariake Bay Area, Japan. International Journal of Geosciences, 5, 595-606. 
herent strength at a high void ratio. Although a reduction in the pore-water salinity of marine sediments due to the flow of groundwater (or its diffusion process) causes little change in the soil structure, it can cause a remarkable change in the interparticle forces, resulting in the development of high sensitivity [1]-[3]. Sensitivity is a measure of the shear strength loss of an undisturbed soil material when it is remolded, and is defined as the ratio of the undisturbed shear strength to the remolded shear strength. A soil material that has a sensitivity greater than 30 and exhibits remolded shear strength less than $0.5 \mathrm{kPa}$ is called quick clay [4]. Quick clay is a soil material that changes from a stiff mass to a viscous fluid when it is thoroughly remolded. Such soil behavior has caused massive landslides in the ground of Scandinavia and eastern Canada, where the ground is composed of marine sediments that were elevated above sea level after the last glacial retreat and were subjected to leaching of salt in pore water [2] [5] [6]. Quick clay is also found in the sediments exposed to freshwater in the Ariake Bay area of Japan [7] [8].

The leaching of salt from pore water in marine sediments forms quick clay, but this does not occur for all sediment. It has been found that quick clay does not develop in Norwegian and Canadian clays that are dominated by divalent cations in pore water [9]-[11]. Similarly, the sediment that did not exhibit quick behavior by saltleaching was found in the Ariake Bay area [12]. In this study, to assess whether or not quick clay develops, leaching is performed in the original and seawater-saturated soil samples of undisturbed Ariake Bay sediments, and the cation composition of pore water is then analyzed.

\section{Materials and Methods}

\subsection{Soil Sample}

The soil sample used in this study was a portion (5.0 to $5.9 \mathrm{~m}$ depth) of the undisturbed sediment obtained by thin-walled tube sampling at the Shiroishi site (Lat. $33^{\circ} 11^{\prime} 8 " \mathrm{~N}$, Long. $130^{\circ} 6^{\prime} 44^{\prime \prime} \mathrm{N}$ ) in the Ariake Bay area, Saga Prefecture, Japan (Figure 1). Two types of soil samples were prepared for testing. One was an original soil sample, and the other was a seawater-saturated soil sample that was obtained by saturating an original soil sample with artificial seawater.

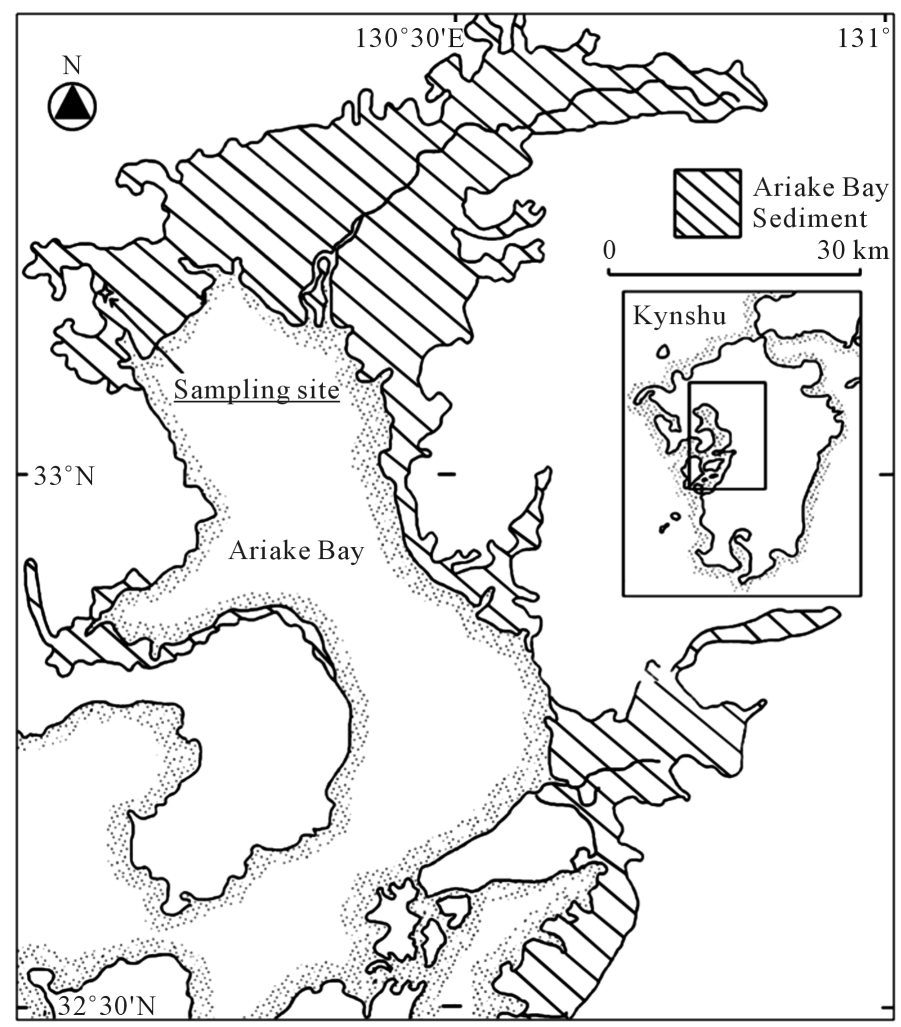

Figure 1. Location of sampling site. 


\subsection{Seawater-Saturated Soil Sample Procedure}

The original soil sample measuring $60 \mathrm{~mm}$ in diameter and $20 \mathrm{~mm}$ in height was prepared by trimming the undisturbed soil sample that was extruded from the thin-walled tube. The trimmed soil sample was placed in a fixed consolidation ring made of brass, measuring $60 \mathrm{~mm}$ in diameter and $20 \mathrm{~mm}$ in height, and allowed to consolidate under a vertical pressure equivalent to the effective overburden pressure on the soil sample in the field. This continued until primary consolidation was completed. Artificial seawater with a typical ion composition (Table 1) was prepared using commercially available seawater powder (Marine Art SF-1, Tomita Pharmaceutical Co., Ltd., Japan). The artificial seawater was introduced from a standpipe with inside diameter of $1.5 \mathrm{~cm}$ into porous stone with a pore size of $0.18 \mathrm{~mm}$; the water was allowed to percolate through the original soil sample (Figure 2). The artificial seawater was left to percolate for one week, until the salinity of leachate from the original soil sample was identical to that of the artificial seawater.

\subsection{Salt-Leaching Procedure}

Leaching for salt removal was conducted on both the original and seawater-saturated soil samples. Soil samples were prepared according to the same procedure as the seawater-saturated soil sample. Deionized water in the standpipe was introduced to the soil samples under an $80 \mathrm{~cm}$ hydraulic head via the porous stone at the bottom of the consolidation ring, and leachate from the upper porous stone was collected every $12 \mathrm{~h}$ for analysis of the pore water chemistry (Figure 2). The leaching process was considered to be complete when a constant minimum salinity was observed in the leachate. In this experiment, a maximum water permeation of $363 \mathrm{~mL}$ was consumed.

Table 1. Chemistry of artificial seawater.

\begin{tabular}{cc}
\hline Chemistry & Value \\
\hline $\mathrm{pH}$ & 8.3 \\
$\mathrm{EC}(\mathrm{mS} / \mathrm{cm})$ & 79 \\
$\mathrm{Na}^{+}(\mathrm{mg} / \mathrm{L})$ & 11,000 \\
$\mathrm{~K}^{+}(\mathrm{mg} / \mathrm{L})$ & 350 \\
$\mathrm{Ca}^{2+}(\mathrm{mg} / \mathrm{L})$ & 340 \\
$\mathrm{Mg}^{2+}(\mathrm{mg} / \mathrm{L})$ & 760 \\
$\mathrm{Cl}^{-}(\mathrm{mg} / \mathrm{L})$ & 19,800 \\
$\mathrm{SO}_{4}^{2-}(\mathrm{mg} / \mathrm{L})$ & 2420 \\
\hline
\end{tabular}

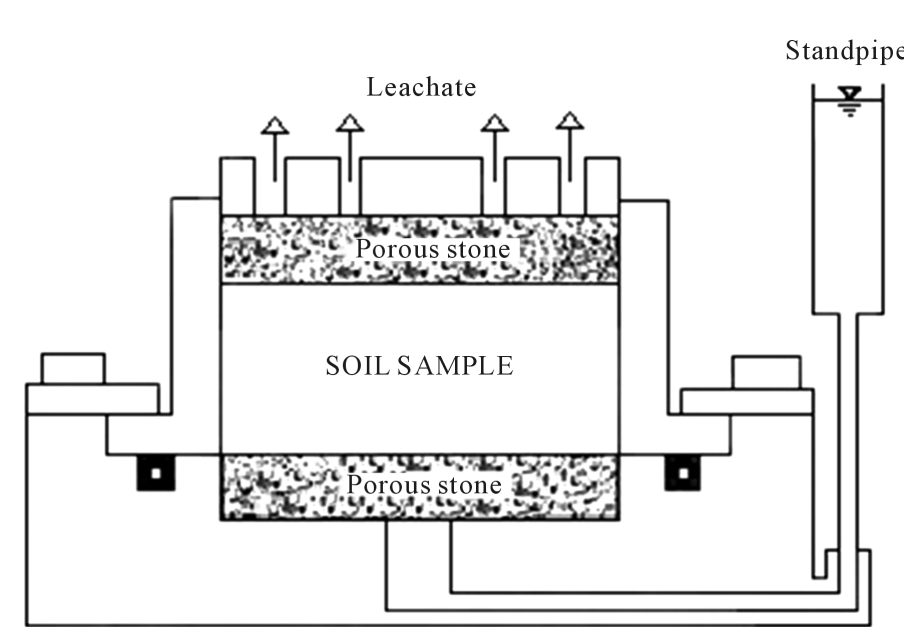

Figure 2. Schemactic diagram of the consolidation ring for leaching. 


\subsection{Permeability Test Procedure}

The permeability of both original and seawater-saturated soil samples during leaching was determined based on the principle of the falling head permeability test. The deionized water in the standpipe was allowed to flow through the soil sample. The quantity of permeating water was measured by observing the rate of water level reduction within the standpipe as a function of time. The soil samples' coefficients of permeability were computed using Equation (1) [13].

$$
k=\frac{2.3 a L}{A\left(t_{1}-t_{2}\right)} \log _{10} \frac{h_{1}}{h_{2}}
$$

where $a$ is the cross-section area of the standpipe, $L$ is the thickness of the soil sample in the consolidation ring, $A$ is the cross-sectional area of the consolidation ring, $t_{1}$ is the time at which the water level in the standpipe is at $h_{1}, t_{2}$ is the time at which the water level in the standpipe is at $h_{2}$, and $h_{1}$ and $h_{2}$ are the heads between which the permeability is determined.

\subsection{Clay Mineral Identification Procedure}

Original soil sample suspensions for X-ray diffraction analysis were treated with $7 \% \mathrm{H}_{2} \mathrm{O}_{2}$ to remove organic matter, deflocculated by sonification, and then adjusted to a $\mathrm{pH}$ of 10 with $1 \mathrm{M} \mathrm{NaOH}$. The $<2 \mu$ m clay fractions were then siphoned from the soil suspension and collected. Duplicate clay suspensions were prepared, each containing $50 \mathrm{mg}$ of clay fractions. One was saturated with $\mathrm{Mg}^{2+}$ by washing with $0.5 \mathrm{M} \mathrm{MgCl}_{2}$; the other was saturated with $\mathrm{K}^{+}$using $1 \mathrm{M} \mathrm{KCl}$. Excess salt was then removed by washing with water. One cubic centimeter of water, together with an aliquot of the suspension containing $30 \mathrm{mg}$ of clay fractions, was dropped onto a glass slide $(28 \times 48 \mathrm{~mm})$, air-dried, and then X-rayed. The K-saturated specimens were heated first at $300^{\circ} \mathrm{C}$ and then at $550^{\circ} \mathrm{C}$. The Mg-saturated specimens were solvated with glycerol to help identify smectite. The treated specimens were subjected to a Rigaku diffractometer with Ni-filtered $\mathrm{CuK} \alpha$ radiation at $40 \mathrm{kV}$ and $20 \mathrm{~mA}$, with a scanning speed of $2^{\circ} 2 \theta \mathrm{mm}^{-1}$, a scanning step of $0.02^{\circ}$, and a scanning mode in a range of $3^{\circ}$ to $30^{\circ} 2 \theta$.

\subsection{Testing Procedures for Soil Sample Properties}

The pore water chemistry was determined using the leachate and the squeezed solutions from the original and seawater-saturated soil samples. The leachate was collected every $12 \mathrm{~h}$ during leaching. For squeezed solutions, a $50 \mathrm{~g}$ soil sample before and after leaching was placed in a separatory funnel and pore water was squeezed through a mini-pore filter with a pore size of $1.0 \mu \mathrm{m}$ using vacuum filtration. Electric conductivity (EC), the concentrations of $\mathrm{Na}^{+}, \mathrm{Ca}^{2+}$, and $\mathrm{K}^{+}$, and $\mathrm{pH}$ for both the leachate and squeezed solutions were determined using LAQUA Twin meters (Horiba Co. Ltd., Japan). The salinity (mg/L) of the soil sample solutions was calculated by multiplying 640 by EC $(\mathrm{mS} / \mathrm{cm})$ [14], which was regarded as pore water salinity. The concentrations of $\mathrm{Cl}^{-}$ and $\mathrm{SO}_{4}^{2-}$ were determined using a portable water quality analyzer (pHotoFlexTurb, Merck, Central Kagaku, Ltd., Japan). The concentration of $\mathrm{Mg}^{2+}$ was determined by means of an atomic absorption spectrophotometer (AAS-Solar 52 Thermo Electronic Cooperation).

The particle size distribution of the original soil sample was obtained by a hydrometer method. Fifteen grams of original air-dried soil sample was mixed with $250 \mathrm{~mL}$ deionized water in a $500 \mathrm{~mL}$ beaker, and $100 \mathrm{~mL} 6 \%$ $\mathrm{H}_{2} \mathrm{O}_{2}$ was added to remove organic matter from the soil sample with addition of $1 \mathrm{M} \mathrm{NaOH}$, and soil suspension was then subjected to analysis.

The liquid limit was determined by measuring the water content at the number of 25 blows required to close a specific width groove for a specified length in a standard liquid limit device. The plastic limit was determined by measuring the water content of the soil samples when threads of the soil sample $3 \mathrm{~mm}$ in diameter began to crumble.

The undisturbed shear strength was determined using a consolidated constant-volume box-shear test. Before and after leaching, the soil sample measuring $60 \mathrm{~mm}$ in diameter and $20 \mathrm{~mm}$ in height was placed in a shear box and consolidated under a vertical pressure of 24.9 to $27.0 \mathrm{kPa}$, equivalent to the effective overburden pressure on the soil sample in the field. After completion of primary consolidation, the soil samples were subjected to shearing.

The shear strength of the remolded soil samples was determined using the vane shear apparatus, with a vane 
measuring $16 \mathrm{~mm}$ in width and $32 \mathrm{~mm}$ in height. First, the soil sample was remolded thoroughly by hand; then, it was placed in a container made of vinyl chloride measuring $31 \mathrm{~mm}$ in diameter and $50 \mathrm{~mm}$ in height. The vane was then gently inserted into the remolded soil sample, until the top of the vane reached under the surface of the sample. The vane was then rotated at a speed of 6 degrees per minute, until the shear stress reached a constant value. The remolded strength (peak shear stress) was computed from Equation (2), assuming that the soil sample was isotropic in strength [15].

$$
S_{u r}=\frac{M_{\max }}{\frac{\pi D^{2} H}{2}+\frac{\pi D^{3}}{12}}
$$

where $S_{u r}$ is the remolded shear strength, $M_{\max }$ is the maximum value of torque, $D$ is the width of the vane, and $H$ is the height of the vane.

\section{Results}

\subsection{Properties of Original Soil}

The chemical and physical properties of the original soil sample used for the study were determined (Table 2). The salinity of the pore water of the original soil sample was equal to $11 \%$ of that of sea water, and divalent cations were dominant.

\subsection{Clay Mineral Identification}

An indication of the X-ray diffraction (XRD) patterns for the $<2 \mu \mathrm{m}$ clay fractions of the original soil sample (Table 2) was obtained through the application of various treatments (Figure 3). XRD of the original soil sample demonstrated that the Mg air-dried specimen produced a $1.52 \mathrm{~nm}$ peak, which shifted to a $1.83 \mathrm{~nm}$ peak after glycerol solvation; this indicates the presence of a considerable amount of smectite. The presence of vermiculite was identified by the $1.41 \mathrm{~nm}$ peak, which remained after glycerol solvation. The peaks at 1.0, 0.50, and $0.33 \mathrm{~nm}$ for the Mg air-dried specimen were unchanged by other treatments, indicating the presence of illite. Kaolinite

Table 2. Chemical and physical properties of original soil sample.

\begin{tabular}{cc}
\hline \multicolumn{1}{c}{ Properties } & Values \\
\hline Soil $\mathrm{pH}$ & 8.4 \\
Pore-water chemistry & 3.9 \\
Salinity (g/L) & 150 \\
$\mathrm{Na}^{+}(\mathrm{mg} / \mathrm{L})$ & 39 \\
$\mathrm{~K}^{+}(\mathrm{mg} / \mathrm{L})$ & 440 \\
$\mathrm{Ca}^{2+}(\mathrm{mg} / \mathrm{L})$ & 232 \\
$\mathrm{Mg}^{2+}(\mathrm{mg} / \mathrm{L})$ & \\
$\mathrm{Particle} \mathrm{size}$ & 62.0 \\
$\left.\mathrm{Clay}_{(<5} \mu \mathrm{m}\right)$ & 32.0 \\
Silt (5 - $75 \mu \mathrm{m})$ & 6.0 \\
Sand $(75 \mu \mathrm{m}-2 \mathrm{~mm})$ & \\
Index properties & 144.0 \\
Natural water content $(\%)$ & 102.9 \\
Liquid limit (\%) & 44.6 \\
Plastic limit $(\%)$ &
\end{tabular}


was identified by the $0.71 \mathrm{~nm}$ peaks in the $\mathrm{Mg}$ and $\mathrm{K}$ air-dried specimens and by the disappearance of the peak at $550^{\circ} \mathrm{C}$. Finally, the peak at $0.33 \mathrm{~nm}$ indicates the presence of quartz.

\subsection{Changes in Soil Samples' Coefficients of Permeability during Leaching}

The soil samples' coefficients of permeability, plotted as a function of the pore volume, were changed during leaching (Figure 4). The pore volume (PV) is defined as the ratio of the volume of influent leachate divided by the pore volume of the soil sample. The permeability exhibited an increase as pore volume increased from 1 to 4 , but a subsequent decrease when pore volume increased beyond 4 for the original soil sample. Conversely, permeability was found to decrease with increasing pore volume across the whole pore volume range for the seawater-saturated soil sample. The increase in permeability of the original soil sample at an early stage of leaching was likely due to the fact that the original soil sample was not fully saturated at the start of the leaching process. The decrease in permeability for both the original and seawater-saturated soil samples is considered to be related to the expansion of the diffusion double layer, which was in turn due to a reduction in pore water salinity (as the volume of the soil samples was constant).

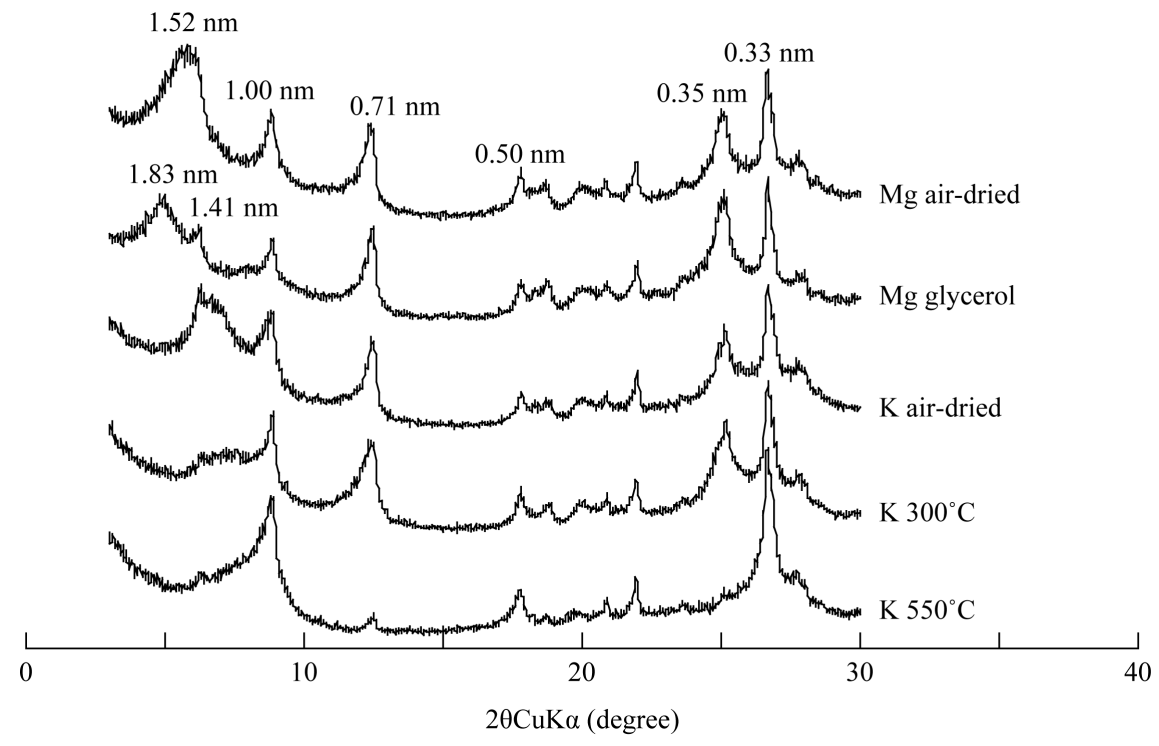

Figure 3. X-ray diffraction patterns for clay fractions subjected to different treatments.

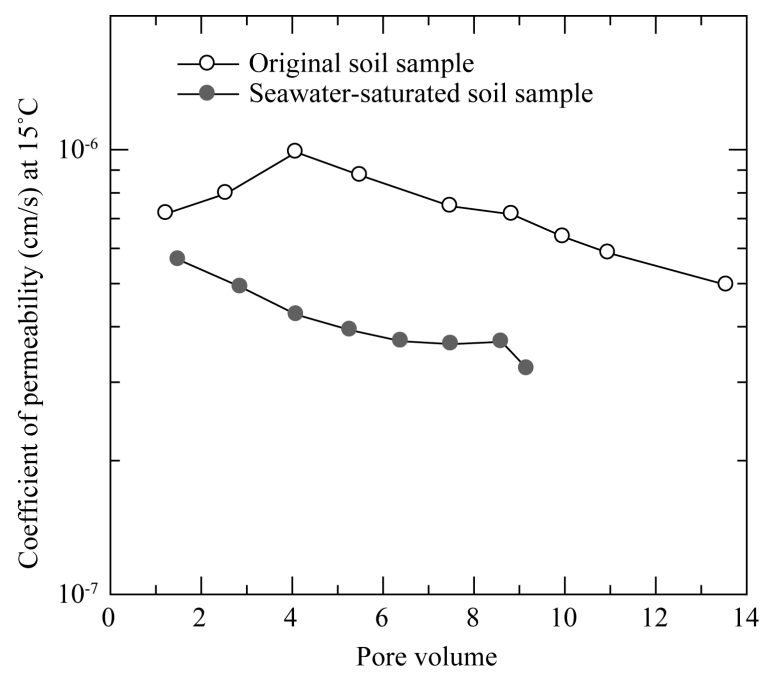

Figure 4. Changes in the soil samples' coefficients of permeability during leaching. 


\subsection{Changes in the Chemistry of Leachate during Leaching}

The chemistry of the leachate was changed during leaching (Figure 5). The $\mathrm{pH}$ of 7.5 to 8.4 for the original soil sample was mostly higher than that for the seawater-saturated soil sample at 7.5 to 8.2 (Figure 5(a)). The EC decreased from 2.6 to $0.13 \mathrm{mS} / \mathrm{cm}$ (1.66 to $0.08 \mathrm{~g} / \mathrm{L}$ for salinity) for the original soil sample, and from 54 to 0.2 $\mathrm{mS} / \mathrm{cm}$ (34.56 to $0.13 \mathrm{~g} / \mathrm{L}$ for salinity) for the seawater-saturated soil sample (Figure 5(b)). The concentrations of $\mathrm{Cl}^{-}$and $\mathrm{SO}_{4}^{2-}$ exhibited a change similar to the EC for both soil samples (Figure 5(c)). The concentrations of all types of cations decreased markedly up to 7 PV and became almost constant beyond 7 PV for both soil samples. However, $\mathrm{Ca}^{2+}$ was dominant for the original soil sample (Figure $5(\mathrm{~d})$ ), whereas $\mathrm{Na}^{+}$was dominant for the seawater-saturated soil sample (Figure 5(e)). This is reflected in Figure 5(f), where the divalent cation percentage is seen to be much higher for the original soil sample $(49.7 \%-73.8 \%)$ than the seawater-saturated soil sample $(1.1 \%-6.4 \%)$ throughout the leaching process.

\subsection{Pore-Water Chemistry Determined from Leachate and Squeezed Solution from Both Soil Sample}

The pore-water chemistry of the soil samples before and after leaching is presented for both the original and seawater-saturated soil samples (Table 3). It was observed that the EC and cation and anion concentrations in the squeezed solutions were higher than those in the leachate. It seems that leaching removes only the salt in free pore water, whereas the process of squeezing extracts salt in the diffuse double layer as well as in the free pore water. The divalent cations occupied $78 \%$ of the pore water in the original soil samples, and this percentage remained almost the same after leaching. However, the pore water in the seawater-saturated soil samples was dominated by $\mathrm{Na}^{+}$; the divalent cation percentage was only $6 \%$, and the pore-water cation proportion was preserved after leaching.

\subsection{Undisturbed and Remolded Shear Strengths of the Soil Sample before and after Leaching}

The shear strength tests were performed on the undisturbed and remolded soil samples, before and after leaching, for both the original and seawater-saturated soil samples (Figure 6). Both undisturbed soil samples were seen to exhibit sharp shear stress versus horizontal displacement curves, and the peak shear stress appeared at a displacement of 0.5 to $0.8 \mathrm{~mm}$. By leaching, the shear strength decreased from 18.43 to $17.32 \mathrm{kPa}$ for the original

Table 3. Pore-water chemistry of the leachate and squeezed solutions from the soil samples.

\begin{tabular}{|c|c|c|c|c|c|c|c|c|c|c|}
\hline & \multirow{2}{*}{$\begin{array}{c}\text { EC } \\
(\mathrm{mS} / \mathrm{cm})\end{array}$} & \multirow{2}{*}{$\mathrm{pH}$} & \multicolumn{4}{|c|}{ Pore-water cation (mg/L) } & \multirow{2}{*}{$\begin{array}{c}\text { Total } \\
\text { cation } \\
(\mathrm{mg} / \mathrm{L})\end{array}$} & \multirow{2}{*}{$\begin{array}{c}\text { Divalent } \\
\text { cation ratio } \\
\text { (\%) }\end{array}$} & \multicolumn{2}{|c|}{$\begin{array}{l}\text { Pore-water anion } \\
\quad(\mathrm{mg} / \mathrm{L})\end{array}$} \\
\hline & & & $\mathrm{Na}^{+}$ & $\mathrm{K}^{+}$ & $\mathrm{Ca}^{2+}$ & $\mathrm{Mg}^{2+}$ & & & $\mathrm{Cl}^{-}$ & $\mathrm{SO}_{4}^{2-}$ \\
\hline \multicolumn{11}{|l|}{ Original soil sample } \\
\hline \multicolumn{11}{|l|}{ Before leaching } \\
\hline Squeezed solution & 6.20 & 8.4 & 150 & 39 & 440 & 232 & 861 & 78 & 125 & 1000 \\
\hline \multicolumn{11}{|l|}{ After leaching } \\
\hline Leachate & 0.13 & 7.5 & 7 & 3 & 24 & 4 & 38 & 74 & 10 & 8 \\
\hline Squeezed solution & 2.80 & 8.5 & 49 & 22 & 270 & 162 & 503 & 86 & 117 & 350 \\
\hline \multicolumn{11}{|l|}{ Seawater-saturated soil sample } \\
\hline \multicolumn{11}{|l|}{ Before leaching } \\
\hline Squeezed solution & 54.00 & 8.4 & 9300 & 320 & 390 & 246 & 10256 & 6 & 18900 & 4100 \\
\hline \multicolumn{11}{|l|}{ After leaching } \\
\hline Leachate & 0.20 & 7.5 & 39 & 1 & 1 & $<1$ & 41 & 3 & 38 & 10 \\
\hline Squeezed solution & 0.34 & 7.1 & 110 & 6 & 5 & $<1$ & 121 & 5 & 70 & 56 \\
\hline
\end{tabular}




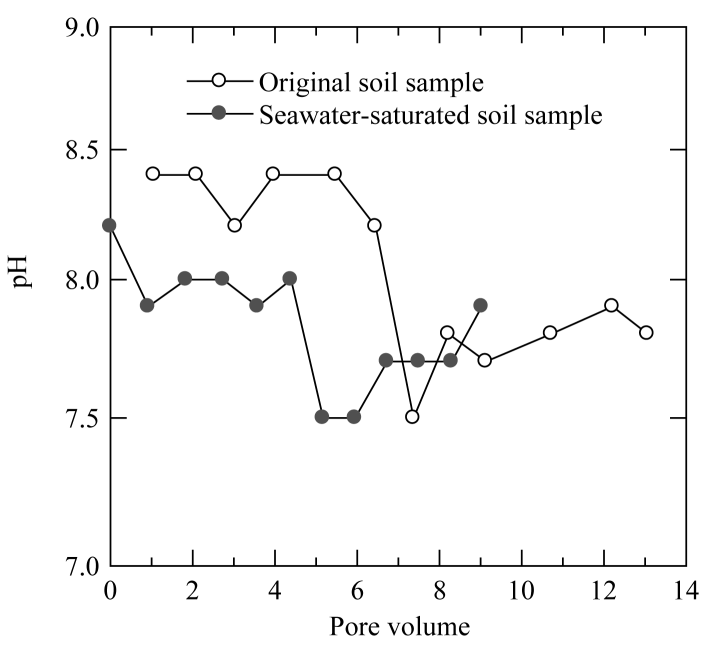

(a)

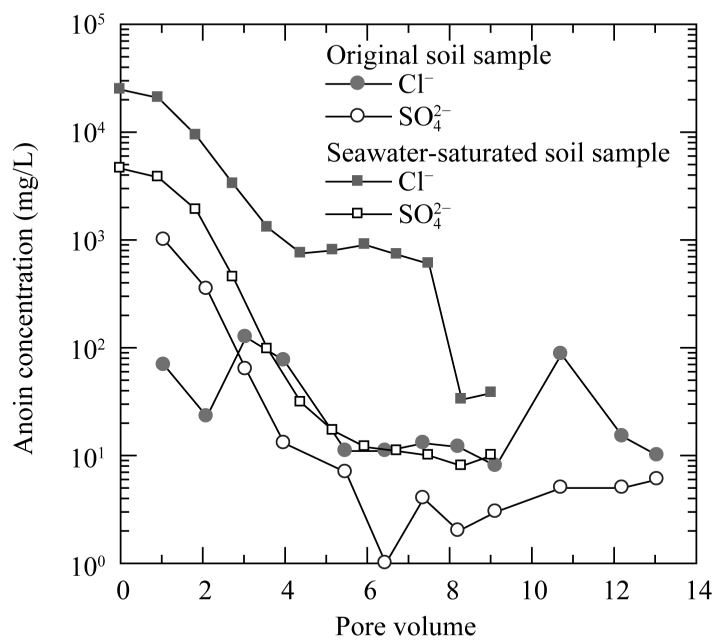

(c)

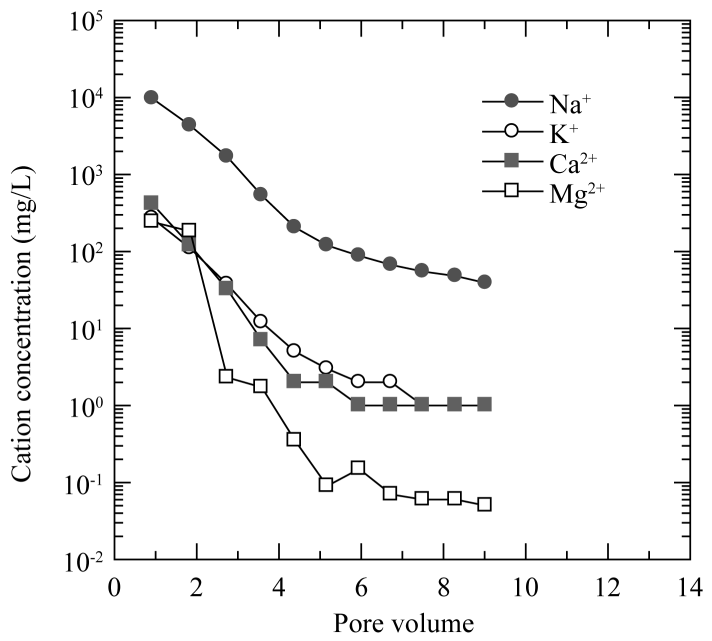

(e)

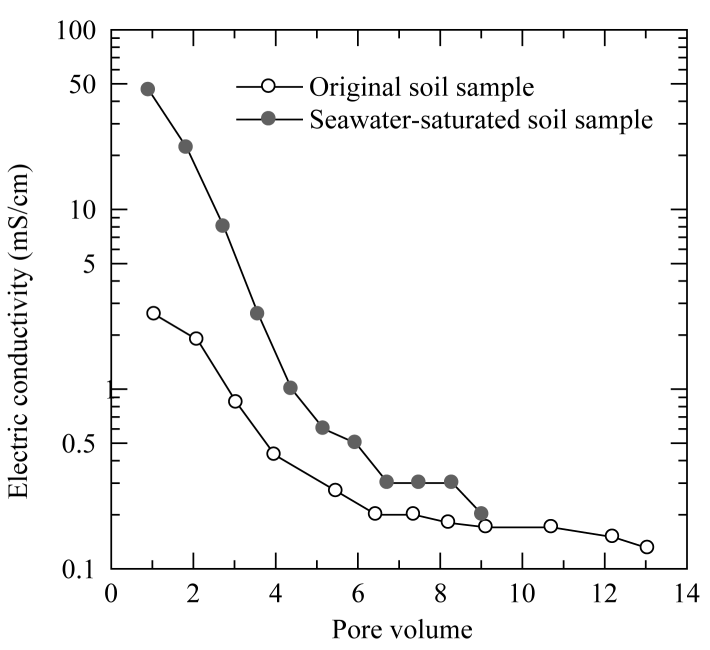

(b)

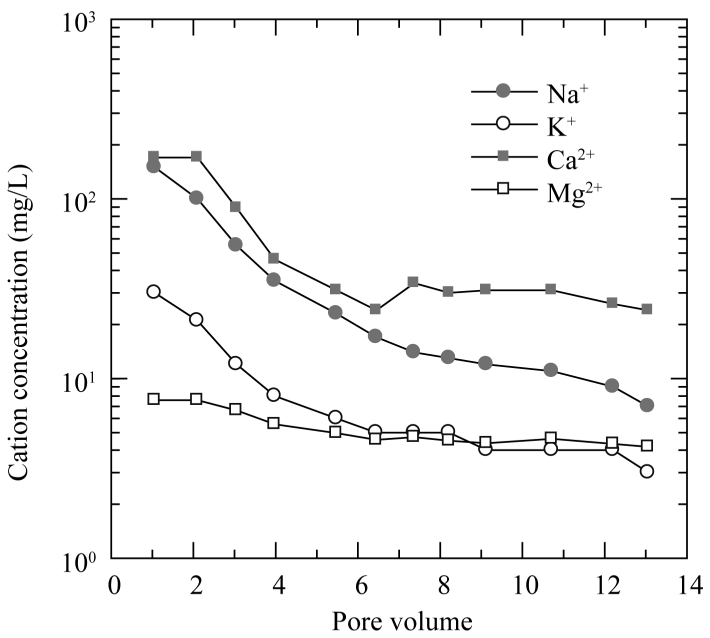

(d)

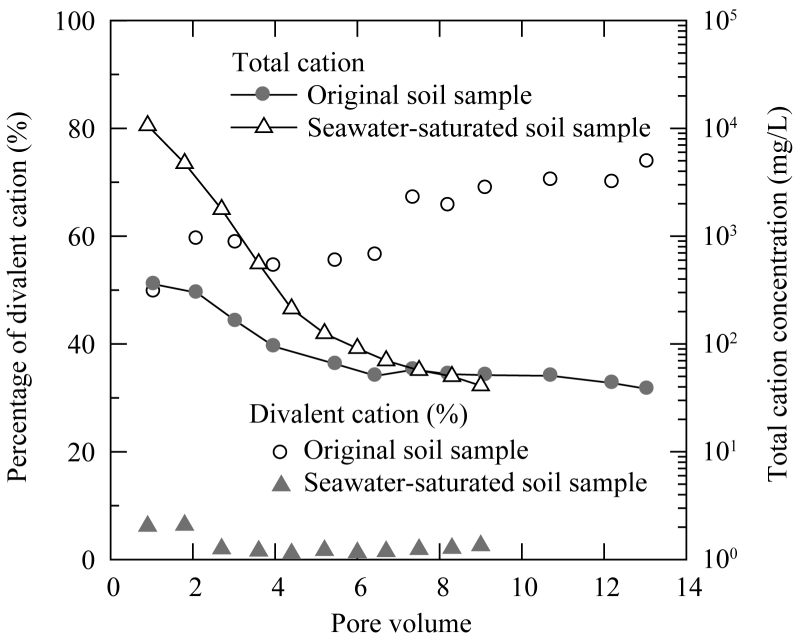

(f)

Figure 5. Changes in the chemistry of the leachate during leaching: (a) $\mathrm{pH}$, (b) electric conductivity, (c) anion concentration, (d) cation concentration for the original soil sample, (e) cation concentration for the seawater-saturated soil sample, (f) total cation concentration and divalent cation percentage. 


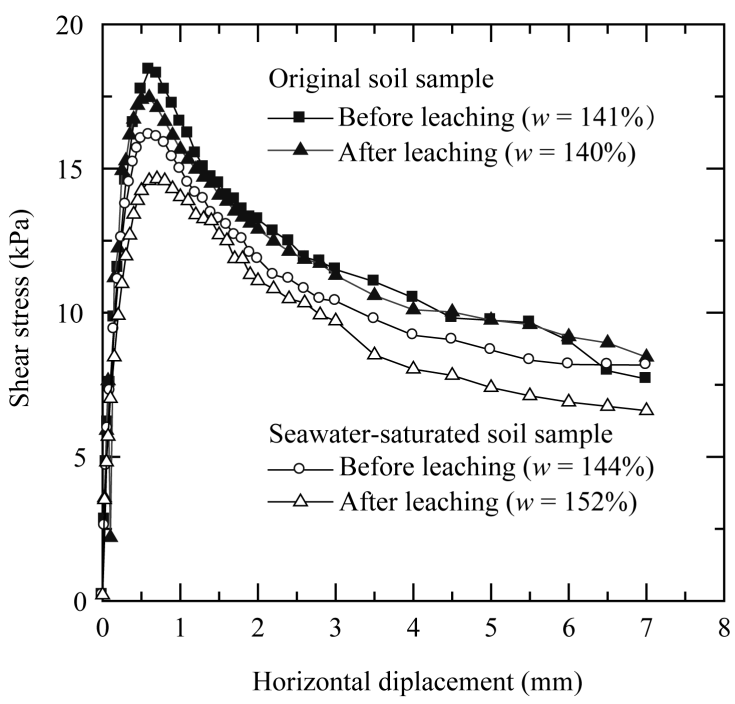

(a)

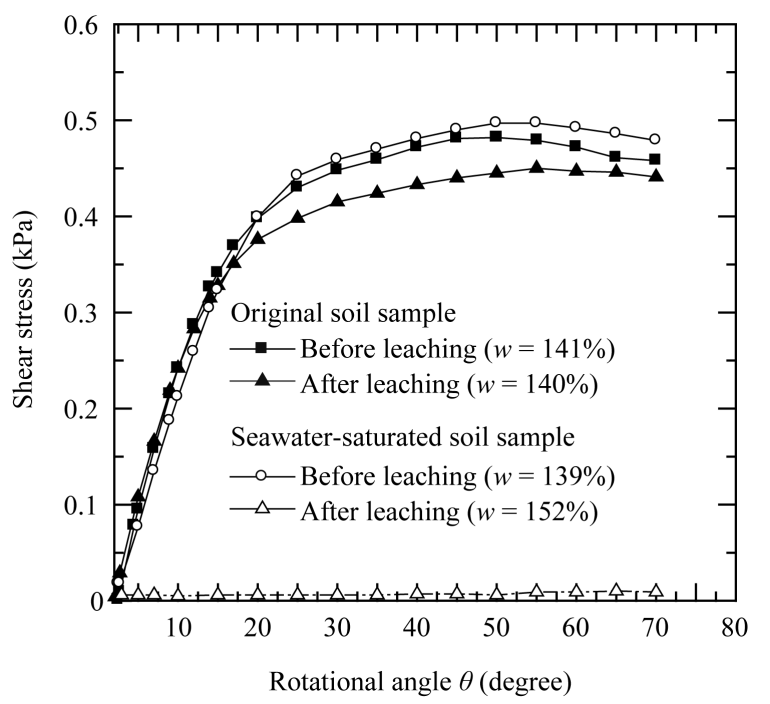

(b)

Figure 6. Shear strength test results on the undisturbed and remolded soil samples before and after leaching: (a) undisturbed shear strength of soil samples before and after leaching, (b) remolded shear strength of soil sample before and after leaching. ( $w$ : water content, defined as the ratio of the weight of water to the weight of solid matter).

soil sample and from 16.16 to $14.64 \mathrm{kPa}$ for the seawater-saturated soil sample (Figure 6(a)). In contrast, the remolded soil samples showed monotonous shear stress versus rotational angle curves, and leaching decreased the remolded shear strength from 0.42 to $0.40 \mathrm{kPa}$ for the original soil sample; leaching decreased the shear stress to an even greater extent in the seawater-saturated soil sample, from 0.48 to $0.02 \mathrm{kPa}$ (Figure 6(b)). The strength test results for other samples are presented (Table 4).

\subsection{Changes in the Geotechnical Properties of the Soil Samples by Leaching}

The geotechnical properties of the soil samples before and after leaching were tested (Table 4). By leaching, the undisturbed shear strength and the $s_{\mathrm{u}} / p$ ratio were decreased slightly in both soil samples. However, although the remolded shear strength was almost unchanged for the original soil sample, it decreased by a large amount for the seawater-saturated soil sample; this resulted in the development of quick clay with a sensitivity exceeding 700. A decrease in the undisturbed shear strength by leaching has also been reported for Norwegian clays [2] [16]. The water content was over $100 \%$ for both the original and seawater-saturated soil samples. This was likely due to the well-developed flocculated structure of the soil samples containing high percentage clay fractions (Table 2). Water content over 100\% is commonly found in Ariake Bay sediments [17]. The liquid and plastic limits were determined using a set of soil samples that were mixed thoroughly after performing the remolded shear strength tests. The liquid limit of both soil samples decreased by leaching, but the extent of reduction in the liquid limit was much greater for the seawater-saturated soil sample than for the original soil sample. These factors led to the higher liquidity index for the seawater-saturated soil sample than for the original soil sample.

\section{Discussion}

The original soil sample used in this study contains smectite as a main clay mineral (Figure 3). Smectite as a principal clay mineral has been found in Ariake Bay sediments at various locations [18]-[20]. Previous studies have reported that the liquid limit and remolded shear strength of Na-montmorillonite (smectite) increase with decreasing pore-water salinity because of the high-swelling characteristics of Na-montmorillonite [21] [22]. Therefore, the high-swelling characteristics of smectite preclude the development of marine sediments containing high-swellling smectite to quick clay when leaching occurs. However, the seawater-saturated soil sample dominated by $\mathrm{Na}^{+}$in pore water, despite consisting of smectite, exhibited decreases in the liquid limit and remolded shear strength through a reduction in pore-water salinity, such that quick clay developed (Table 4). Thus, the response of the liquid limit and remolded shear strength to pore-water salinity for the seawater-saturated soil sample was 
Table 4. Geotechnical properties of soil samples before and after leaching.

\begin{tabular}{|c|c|c|c|c|c|c|c|c|c|}
\hline & \multirow{2}{*}{$\begin{array}{l}\text { Water } \\
\text { content } \\
w(\%)\end{array}$} & \multicolumn{3}{|c|}{ Consistency limit } & \multirow{2}{*}{$\begin{array}{l}\text { Liquidity } \\
\text { index }\end{array}$} & \multicolumn{2}{|c|}{ Shear strength $(\mathrm{kPa})$} & \multirow{2}{*}{$S_{u} / p$} & \multirow{2}{*}{$\begin{array}{l}\text { Sensitivity } \\
\qquad\left(S_{u} / S_{u r}\right)\end{array}$} \\
\hline & & $w_{L}(\%)$ & $w_{p}(\%)$ & $I_{p}$ & & $S_{u}$ & $S_{u r}$ & & \\
\hline \multicolumn{10}{|l|}{ Original soil sample } \\
\hline \multirow[t]{2}{*}{ Before leaching } & 144 & 102.9 & 44.6 & 58.3 & 1.70 & 19.05 & 0.42 & \multirow{2}{*}{0.71} & 45 \\
\hline & 141 & & & & & 18.43 & 0.42 & & 44 \\
\hline \multirow[t]{2}{*}{ After leaching } & 140 & 98.6 & 48.6 & 50.0 & 1.85 & 17.32 & 0.40 & \multirow{2}{*}{0.65} & 43 \\
\hline & 141 & & & & & 16.71 & 0.41 & & 41 \\
\hline \multicolumn{10}{|c|}{ Seawater-saturated soil sample } \\
\hline \multirow[t]{3}{*}{ Before leaching } & 148 & 98.4 & 49.5 & 48.9 & 1.93 & 15.67 & 0.47 & & 33 \\
\hline & 144 & & & & & 16.16 & 0.51 & 0.63 & 32 \\
\hline & 139 & & & & & 17.05 & 0.48 & & 35 \\
\hline \multirow[t]{3}{*}{ After leaching } & 152 & 68.6 & 42.9 & 25.7 & 4.25 & 14.64 & 0.02 & & 771 \\
\hline & 150 & & & & & 14.50 & 0.02 & 0.61 & 853 \\
\hline & 150 & & & & & 15.88 & 0.01 & & 1588 \\
\hline
\end{tabular}

$w$ : water content (defined as the ratio of the weight of water to the weight of solid matter); $w_{L}$ : liquid limit; $w_{p}$ : plastic limit; $I_{p}$ : plasticity index; $S_{u}$ : undisturbed shear strength; $S_{u r}$ : remolded shear strength; $S_{u} / p$ : ratio of undisturbed shear strength to effective overburden pressure.

opposite to that for the high-swelling smectite but similar to that for the soil materials of Scandinavia and eastern Canada, which are typically composed of non-swelling minerals like illite, chlorite, quartz, and feldspar [5] [6] [16]. A decrease in the liquid limit and remolded shear strength due to reduction in pore-water salinity and subsequent development of quick clay has been reported previously for Ariake Bay sediments [7]. This unusual behavior, which differs to that of high-swelling smectite, was assumed to be due to the low-swelling characteristics of smectite in Ariake Bay sediments, and this smectite characteristic has been proved to be true based on sediment volume tests [18]-[20] and swelling pressure tests [23].

By leaching, the remolded shear strength of the seawater-saturated soil sample decreased by $97 \%$, whereas that of the original soil sample decreased by $4 \%$ on average (Table 4). This can be explained in terms of the difference in the cation composition of pore water (squeezed solutions) between the two types of soil samples (Table 3). $\mathrm{Na}^{+}$was the major cation for the seawater-saturated soil sample, but divalent cations were dominant for the original soil sample after leaching. Interparticle attraction was dominant regardless of the type of cation, under high pore-water salinity before leaching, because the diffuse double layer shrinks and high remolded shear strength occurs for both soil samples. As pore-water salinity is decreased by leaching, the interparticle repulsion increases through an expansion of the diffuse double layer in the seawater-saturated soil sample, resulting in marked reductions in the remolded shear strength; in this manner, quick clay is developed. However, in the original soil sample, interparticle attraction was dominant even after leaching; hence, the remolded shear strength and sensitivity were almost the same as before leaching because the dominance of divalent cations suppressed the expansion of the diffuse double layer. Therefore, quick clay did not develop. Some studies have reported the non-development of quick clay after leaching for Norwegian and Canadian clays. Reference [9] indicated that quick clay was not found in leached Canadian clays dominated by divalent cations in pore water. At Drammen in Norway and Touraine in Canada, sensitivity reduction in part of the leached clays was attributed to increased pore-water concentrations of $\mathrm{K}, \mathrm{Ca}$, and $\mathrm{Mg}$ [10] [11] [24].

By leaching, the liquid limit of the original soil sample decreased slightly, whereas that of the seawater-saturated soil sample decreased considerably (Table 4). The liquid limit of soil samples is defined as the water content at which sufficient free water is present to allow soil particles to slip past each other under a force of 25 blows (in the Casagrande liquid limit test) [21]. Because of the dominance of interparticle attraction at high pore-water salinity before leaching, the soil sample is capable of retaining a great deal of water when the soil particles slip past each other, giving both types of soil sample a high liquid limit. A decrease in pore-water salin- 
ity increases interparticle repulsion for the seawater-saturated soil sample and reduces the liquid limit to a great extent, although it has little effect on the interparticle force for the original soil sample, thus decreasing the liquid limit only slightly.

\section{Conclusion}

By leaching, the undisturbed shear strength decreased slightly for both soil samples. However, a large disparity between the soil samples was seen in the remolded shear strength: it remained almost the same for the original soil sample, but decreased considerably for the seawater-saturated soil sample, thus developing a quick clay with a sensitivity exceeding 700 . The lack of development of quick clay in the original soil sample is attributed to the dominance of divalent cations in the pore water, and the development of quick clay in the seawater-saturated soil sample is ascribed to the dominance of $\mathrm{Na}^{+}$in the pore water.

\section{Acknowledgements}

The authors wish to thanks Professor Shin-Ichiro Wada for his valuable comments and suggestions in this paper. Thanks are also extended to Dr. Akiko Nakano and Dr. Tomotaka Morishita for their assistance in conducting laboratory work.

\section{References}

[1] Skempton, A.W. and Northey, R.D. (1952) The Sensitivity of Clays. Geotechnique, 3, 30-53. http://dx.doi.org/10.1680/geot.1952.3.1.30

[2] Bjerrum, J. (1954) Geotechnical Properties of Norwegian Marine Clay. Geotechnique, 4, 49-69. http://dx.doi.org/10.1680/geot.1954.4.2.49

[3] Bjerrum, L. and Rosenqvist, I.Th. (1956) Some Experiments with Artificially Sedimented Clays. Geotechnique, 6, 124-136. http://dx.doi.org/10.1680/geot.1956.6.3.124

[4] Torrance, J.K. (1983) Towards a General Model of Quick Clay Development. Sedimentology, 30, 547-555. http://dx.doi.org/10.1111/j.1365-3091.1983.tb00692.x

[5] Rosenqvist, I.Th. (1953) Considerations on the Sensitivity of Norwegian Quick-Clays. Geotechnique, 3, 195-200. http://dx.doi.org/10.1680/geot.1953.3.5.195

[6] Torrance, J.K. (1975) On the Role of Chemistry in the Development and Behavior of the Sensitive Marine Clays of Canada and Scandinavia. Canadian Geotechnical Journal, 12, 326-335. http://dx.doi.org/10.1139/t75-037

[7] Ohtsubo, M., Takayama, M. and Egashira, K. (1982) Marine Quick Clays from Ariake Bay Area, Japan. Soils and Foundations, 22, 71-80. http://dx.doi.org/10.3208/sandf1972.22.4_71

[8] Miura, N., Akamine, T. and Shimoyama, S. (1996) Study on Depositional Environment of Ariake Clay Formation, and Its Sensitivity. Journal of Geotechnical Engineering, Japan Society of Civil Engineering, 541, 119-131.

[9] Penner, E. (1965) A Study of Sensitivity in Leda Clay. Canadian Journal of Earth Sciences, 2, 425-441. http://dx.doi.org/10.1139/e65-037

[10] Moum, J., Löken, T. and Torrance, J.K. (1971) A Geotechnical Investigation of the Sensitivity of a Normally Consolidated Clay from Drammen, Norway. Geotechnique, 21, 329-340. http://dx.doi.org/10.1680/geot.1971.21.4.329

[11] Torrance, J.K. (1979) Post-Depositional Changes in the Pore Water Chemistry of the Sensitive Marine Clays of the Ottawa Area, Eastern Canada. Engineering Geology, 14, 135-147. http://dx.doi.org/10.1016/0013-7952(79)90081-4

[12] He, P., Ohtsubo, M., Higashi, T. and Kanayama, M. (2012) Consolidation Characteristics of Artificially Prepared Quick Clay. Proceedings of JS-Seoul 2012 International Joint Symposium on Urban Geotechnics for Sustainable Development, Seoul, 2-3 November 2012, 226-229.

[13] Sakai, T., Katsuyama, K., Md. Zakaria, H. and Laura, J. P.N. (2010) Soil Mechanics (1)-Fundamental Properties. Coronasha Publishing Co., Ltd., Tokyo.

[14] Committee for Soil Nutrition Determination Method (1975) Analysis Method of Soil Nutrition (Dojobunsekihou). Yokendo Co. Ltd., Tokyo.

[15] Yamaguchi, H. (1984) Soil Mechanics (All Revision). Gihodoshuppan Co. Ltd., Tokyo.

[16] Torrance, J.K. (1974) A Laboratory Investigation of the Effect of Leaching on the Compressibility and Shear Strength of Norwegian Marine Clays. Geotechnique, 24, 155-173. http://dx.doi.org/10.1680/geot.1974.24.2.155

[17] Ohtsubo, M., Higashi, T., Kanayama, M. and Takayama, M. (2007) Depositional Geochemistry and Geotechnical 
Properties of Marine Clays in the Ariake Bay Area, Japan. Proceedings of the Second International Workshop on Characterisation and Engineering Properties of Natural Soils, Singapore, 29 November-1 December 2006, 1893-1937.

[18] Egashira, K. and Ohtsubo, M. (1981) Low-Swelling Smectite in a Recent Marine Mud of Ariake Bay. Soil Science and Plant Nutrition, 27, 205-211. http://dx.doi.org/10.1080/00380768.1981.10431272

[19] Egashira, K. and Ohtsubo, M. (1982) Smectite in Marine Quick-Clay of Japan. Clays and Clay Minerals, 30, $275-280$. http://dx.doi.org/10.1346/CCMN.1982.0300404

[20] Egashira, K. and Ohtsubo, M. (1983) Swelling and Mineralogy of Smectite in Paddy Soils Derived from Marine Alluvium, Japan. Geoderma, 29, 119-127. http://dx.doi.org/10.1016/0016-7061(83)90036-8

[21] Warkentin, B.P. (1961) Interpretation of the Upper Plastic Limit of Clays. Nature, 190, 287-288. http://dx.doi.org/10.1038/190287a0

[22] Warkentin, B.P. and Yong, R.N. (1962) Shear Strength of Montmorillonite and Kaolinite Related to Interparticle Forces. Clays and Clay Minerals, 9, 210-218. http://dx.doi.org/10.1346/CCMN.1960.0090111

[23] Ohtsubo, M., Takayama, M. and Egashira, K. (1985) Properties of a Low-Swelling Smectite Marine Clay of Interest in Soil Engineering. Canadian Geotechnical Journal, 22, 241-245. http://dx.doi.org/10.1139/t85-033

[24] Moum, J., Löken, T. and Torrance, J.K. (1972) A Geotechnical Investigation of a Normally Consolidated Clay from Drammen, Norway, Discussion. Geotechnique, 22, 542-544. http://dx.doi.org/10.1680/geot.1972.22.3.542. 